\title{
Polymer brush coatings regulating cell behavior: Passive interfaces turn into active
}

Citation for published version (APA):

Moroni, L., Gunnewiek, M. K., \& Benetti, E. M. (2014). Polymer brush coatings regulating cell behavior: Passive interfaces turn into active. Acta Biomaterialia, 10(6), 2367-2378.

https://doi.org/10.1016/j.actbio.2014.02.048

Document status and date:

Published: 01/06/2014

DOI:

10.1016/j.actbio.2014.02.048

Document Version:

Publisher's PDF, also known as Version of record

Document license:

Taverne

Please check the document version of this publication:

- A submitted manuscript is the version of the article upon submission and before peer-review. There can be important differences between the submitted version and the official published version of record.

People interested in the research are advised to contact the author for the final version of the publication, or visit the DOI to the publisher's website.

- The final author version and the galley proof are versions of the publication after peer review.

- The final published version features the final layout of the paper including the volume, issue and page numbers.

Link to publication

\footnotetext{
General rights rights.

- You may freely distribute the URL identifying the publication in the public portal. please follow below link for the End User Agreement:

www.umlib.nl/taverne-license

Take down policy

If you believe that this document breaches copyright please contact us at:

repository@maastrichtuniversity.nl

providing details and we will investigate your claim.
}

Copyright and moral rights for the publications made accessible in the public portal are retained by the authors and/or other copyright owners and it is a condition of accessing publications that users recognise and abide by the legal requirements associated with these

- Users may download and print one copy of any publication from the public portal for the purpose of private study or research.

- You may not further distribute the material or use it for any profit-making activity or commercial gain

If the publication is distributed under the terms of Article $25 \mathrm{fa}$ of the Dutch Copyright Act, indicated by the "Taverne" license above, 
Review

\title{
Polymer brush coatings regulating cell behavior: Passive interfaces turn into active
}

\author{
Lorenzo Moroni ${ }^{\mathrm{a}, \mathrm{d}}$, Michel Klein Gunnewiek ${ }^{\mathrm{b}}$, Edmondo M. Benetti ${ }^{\mathrm{b}, \mathrm{c}, *}$ \\ ${ }^{a}$ Department of Tissue Regeneration, MIRA Institute for Biomedical Technology and Technical Medicine, University of Twente, P.O. Box 217, 7500 AE Enschede, The Netherlands \\ ${ }^{\mathrm{b}}$ Department of Materials Science and Technology of Polymers, MESA+ Institute for Nanotechnology, University of Twente, P.O. Box 217, 7500 AE Enschede, The Netherlands \\ ${ }^{\mathrm{c}}$ Laboratory for Surface Science and Technology, Department of Materials, ETH Zurich, Vladimir-Prelog-Weg 5, 8093 Zurich, Switzerland \\ ${ }^{\mathrm{d}}$ Department of Complex Tissue Regeneration, Faculty of Health, Medicine and Life Sciences, Maastricht University, P.O. Box 616, 6200MD Maastricht, The Netherlands
}

\section{A R T I C L E I N F O}

\section{Article history:}

Received 18 December 2013

Received in revised form 20 February 2014

Accepted 25 February 2014

Available online 4 March 2014

Keywords:

Polymer brush

Cells

Biomaterials

Surface-initiated polymerization

Biointerfaces

\begin{abstract}
A B S T R A C T
Material technology platforms able to modulate the communication with cells at the interface of biomaterials are being increasingly experimented. Progress in the fabrication of supports is simultaneously introducing new surface modification strategies aimed at turning these supports from passive to active components in engineered preparations. Among these platforms, polymer brushes are arising not only as coatings determining the physical and (bio)chemical surface properties of biomaterials, but also as smart linkers between surfaces and biological cues. Their peculiar properties, especially when brushes are synthesized by "grafting-from" methods, enable closer mimicking of the complex and heterogeneous biological microenvironments.

Inspired by the growing interest in this field of materials science, we summarize here the most prominent and recent advances in the synthesis of "grafted-from" polymer brush surfaces to modulate the response of adhering cells.
\end{abstract}

(c) 2014 Acta Materialia Inc. Published by Elsevier Ltd. All rights reserved.

\section{Introduction}

During the last two decades increasing efforts have been dedicated to tailor the chemical, biological and physical properties of supports and scaffolds meant to function as platforms for the attachment, proliferation and differentiation of cells [1]. One of the main goals has been to design interfaces capable of triggering a specific cell response by including the appropriate biological functions and by mimicking the natural extracellular matrix (ECM) counterpart [2]. In addition, the rise of tissue engineering approaches $[3,4]$ stimulated the application of chemical surface modification strategies in order to mechanically support the regeneration of tissues in a biocompatible and naturally degradable environment [5]. This often encompassed fabrication strategies to control and precisely determine interfacial stiffness, wettability and the loading of biological functions (such as cell adhesive units or growth factors) [6-9].

These objectives were applied on test surfaces and more structured supports by applying either chemical modification by physical

\footnotetext{
* Corresponding author at: Laboratory for Surface Science and Technology, Department of Materials, ETH Zurich, Vladimir-Prelog-Weg 5, 8093 Zurich Switzerland. Tel.: +41 4463260 74; fax: +41446331027.

E-mail address: edmondo.benetti@mat.ethz.ch (E.M. Benetti).
}

treatment or self-assembled monolayers (SAMs) with variable chemistries. The first approach could be applied to a variety of supports, and often comprised physical and chemical oxidation in order to gain surface functions or simply tune the wettability. SAMs were successfully proved to be extremely versatile methods for the precise tailoring of the surface chemistry of cell platforms [10]. Nevertheless, SAMs suffered restricted applicability on most of the biodegradable architectures used for housing cell manipulations. To overcome these limitations and concomitantly broaden the possibilities of both chemical and physical surface modification, "macromolecular" approaches for the functionalization of biointerfaces have recently emerged to prominence as extremely promising methods [11]. This general strategy relied on the surface tethering of polymeric species which can be assembled, grown or generally grafted onto the target surfaces via covalent or physical interactions $[12,13]$. These assemblies of macromolecules, also termed polymer brushes [14], were successfully applied to both metallic and organic surfaces, acting as versatile coatings for a wide variety of applications in biomaterials science. Dense polymer brush layers present a number of peculiar properties, which justify their widespread application in the designing of biointerfaces. The most relevant can be summarized as: (i) controlled swelling and wettability (which govern biofouling equilibrium); (ii) multifunctional character (to allow bioconjugation); (iii) adjustable macromolecular 
parameters (such as molar mass or grafting density); and (iv) full compatibility to most of the support chemistries. Both "graftingfrom" [15] and "grafting-to" [16] techniques have been studied and applied for the preparation of brush platforms for cell adhesion and proliferation. However, "grafting-from" techniques allowed the generation of denser assemblies featuring fully tunable structural properties, such as grafting density and film thickness. With this aim in mind, controlled surface-initiated polymerization (SIP) and radical processes, in particular, were increasingly developed and refined during the last decade, providing "living" and "quasi-living" growths of macromolecules from surface-immobilized initiators [12]. The impossibility to rely on direct methods for the chemical characterization of "grafted-from" polymer brushes often generated a certain uncertainty on the macromolecular parameters such as brush polydispersity and molar mass determination. Despite these drawbacks, recently developed fabrication methods allowed the synthesis of "grafted-from" brushes from large area substrates (or specific areas) which, following chain detachment or etching, provided sufficient amounts of polymer solutions for characterization [17-20].

Thus, thanks to the ongoing advances in controlled SIP, it is possible to enable not only a precise control over brush chain length (brush thickness), but also over brush polydispersities and chain end-functions exposed at the interface $[21,22]$. Specifically, atom transfer radical (ATRP) [23,24], initiator-transfer terminator (INIFERTER) [25] and reversible addition-fragmentation chain transfer (RAFT) [26] polymerizations have been the most widely applied for the modification of organic and inorganic supports. With these methods not only homopolymer but also block- and random-copolyomer brushes [27-32] were successfully fabricated featuring a large number of chemistries and different macromolecular architectures, such as graft- or hyperbranched co-polyomers [33].

All these methods were used for the synthesis of polymer brush biointerfaces to repel unspecific protein adsorption or successfully deplete bacteria attachment onto surfaces thanks to the excellent antibiofouling properties of densely packed, highly hydrated brushes [34]. Some of these characteristics were also exploited to broaden the utilization of polymer brush coatings to form "intelligent" surfaces, closely mimicking ECM characteristics, for the manipulation of cells [35]. In this regard, we focus here on reviewing the fabrication and application of polymer brush layers as a platform to study cell activity with the aim of integrating brush coatings within new formulations for the engineering of biomaterials.

The spotlight of this study is centred on "grafting-from" methods for the synthesis of thick brushes, given their versatility and universal effectiveness. Starting from poly(ethylene glycol) (PEG)based brush systems by SIP, which have historically been among the first systems to be used for biomedical applications, we will summarize the most relevant brush surfaces presenting different chemistries, which were applied as cell-sensitive substrates. We will then describe the latest developments in the synthesis of thermoresponsive brush interfaces, which have been successfully employed for reversible cell adhesion, cell separation and cell sheet engineering. The last section of this review reports the most recent advances in the designing of polymer brush coatings for stem cell manipulations. Particular attention will be devoted in this last section to the application of well-determined brush chemistries and the employment of their peculiar physical properties for tissue engineering and regenerative medicine.

\section{Bioactive polymer brushes: from PEGs to multifunctional grafts}

With the adjective "bioactive" referring to polymer brush surfaces, we define those assemblies of densely grafted macromole- cules which, due to their peculiar chemistries and/or physical characteristics, are able to determine the response of adhering cells towards particular metabolic or morphological behavior. This high potential of brush coatings is a direct consequence of their tunable chemical and physical properties, which make them ideal platforms to simulate distinct interfacial environments that could mimic those of natural ECM.

Among the wide variety of hydrophilic polymers which have been tested to date for the fabrication of brush biointerfaces, the "gold standard" is represented by PEG and its derivatives, grafted through diverse strategies on a number of solid supports. Given its high hydrophilicity, PEG-based adsorbates were classically applied to confer a biopassive character to metallic and non-metallic surfaces. Linear, hyperbranched and dendronized PEG films were thus produced in order to provide inert interfaces in biological media [36-38]. Nevertheless, the requirement of enhanced bioconjugation of biological cues to promote biospecific cell responses on otherwise inert PEG surfaces increasingly triggered the use of radically polymerizable PEG- or oligo(ethylene glycol) (OEG)-containing (macro)monomers to be applied together with SIP in the synthesis of thick, dense and functional brush coatings [39]. These species, compared to end-functional or co-polyomer PEG-based adsorbates, could be easily grafted from initiator-activated supports either by surface-initiated aqueous ATRP or by other radical methods [39-48]. The use of hydroxyl-terminated OEG and PEG methacrylate/acrylate species thus allowed the fabrication of brush films with multiple anchoring points, the concentration of which could furthermore be adjusted by varying the degree of polymerization and thus the chain length and brush film thickness [43]. In addition, the length of the PEG side unit could be varied by appropriately choosing the (macro)monomer type to obtain different swelling and mechanical properties of the films [41]. This modularity associated with its inert character resulted in great interest in PEG-based brushes as a potential blank platform onto which different biological moieties could be engineered to study how the biological microenvironment can be decoupled.

OEG-polymethacrylate (POEGMA) brushes were reported to form cell adhesive polymer bioconjugates via either chain ends or side chain coupling of cell-cues like RGD peptides or fibronectin (FN) [41], growth factors (GFs) [49], or collagen type I [43]. On endfunctionalized surface-grafted POEGMA brushes bioadhesive proteins were exposed at the ECM interface keeping the underlying brush un-functionalized. By this method Klok et al. proved a relevant effect of the brush architecture, i.e. PEG side chain length, on the morphology of adhering human umbilical vascular endothelial cells (HUVECs) [41] (Fig. 1). In this study RGD-functionalized POEGMA brushes featuring different OEG side chain lengths were reported to induce different densities of focal adhesion complexes, and thus integrin-ligand affinities, as a result of diverse brush swelling.

In order to tune the physical properties and the cell adhesive character of POEGMA brushes, the surface grafting density was also varied by diluting the initiator of the starting monolayers. By this approach, polymer grafting densities ranging from 0.02 to 0.35 chains $\mathrm{nm}^{-2}$ were obtained. Subsequent physical adsorption of RGD-containing peptides showed a consequent variation in peptide loading within the brush from around 0.2 to $0 \mathrm{ng} \mathrm{mm}^{-2}$ in the case of the most diluted and densest brushes, respectively [45]. This variation in peptide concentration in the brush architecture thus translated into a different number of adhering MC3T3 cells among the different peptide-bearing films.

Following similar fabrications based on surface-initiated ATRP, random co-polyomer brushes of 2-(2-methoxyethoxy)ethyl methacrylate $\left(\mathrm{MEO}_{2} \mathrm{MA}\right)$ and OEGMA [50] were prepared to produce switchable fouling/non-fouling surfaces for the controlled adhesion and subsequent detachment of various cell types (Fig. 2). 
a
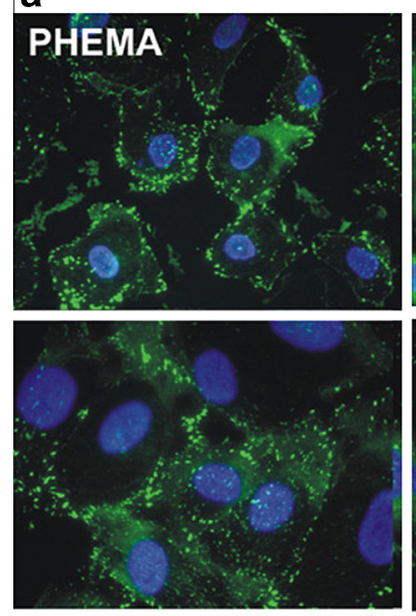
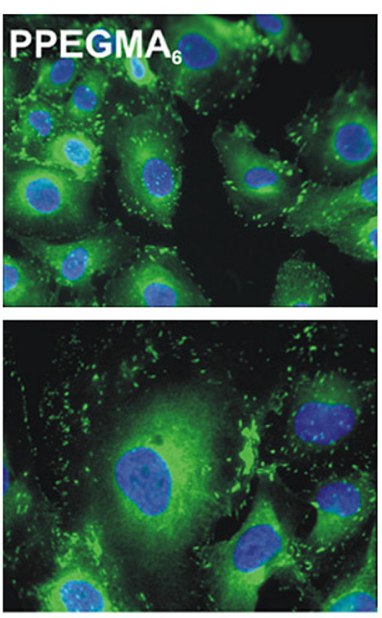

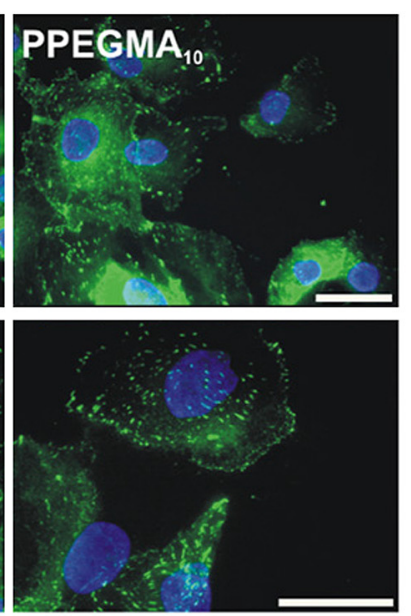

b

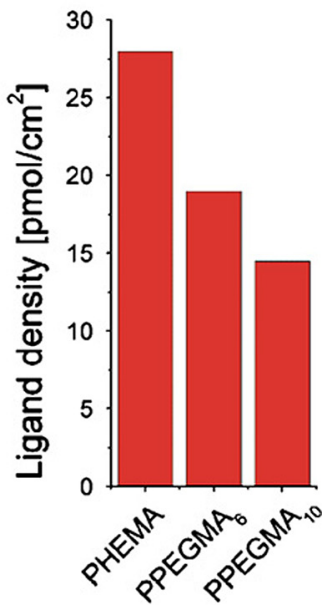

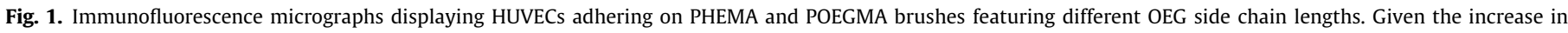

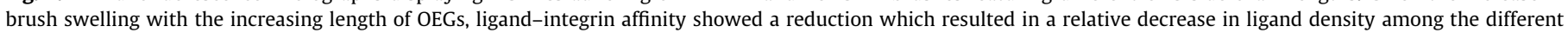
brush surfaces tested. Figure adapted with permission from [41].

These brush surfaces showed a sharp transition from the swollen hydrophilic to the collapsed hydrophobic state across a physiological temperature range $\left(30-35^{\circ} \mathrm{C}\right)[51,52]$. Thus, cells were harvested at $37^{\circ} \mathrm{C}$, allowing stable surface attachment without the need of any adhesive cue, while they were released by lowering the culture temperature to $25^{\circ} \mathrm{C}$ following a completely reversible process without any change of cell viability.

These temperature-responsive brushes were applied for the controlled attachment/detachment of both L929 mouse fibroblast and MCF-7 breast cancer cells, demonstrating how different cell lines follow distinct adhesion and desorption mechanisms on brush-coated surfaces [53].

The temperature-driven transition of some OEG-based amphiphilic brushes was subsequently exploited for the fabrication of cell sheets and their isolation, providing a potential study platform for the generation of artificial epidermis components [54]. This method allowed the formation of a confluent fibroblast film after $24 \mathrm{~h}$ followed by uniform and ready lifting off of the cell sheet by lowering the temperature below $20^{\circ} \mathrm{C}$, as depicted in Fig. 3 .

Despite the widespread application of PEG-based coatings in the designing of biologically inert and highly functionalizable brush coatings, a new class of biocompatible polymers based on poly(2-oxazoline)s (POXs) has recently emerged [55-57]. These polymers have been increasingly been applied for the synthesis of drug delivery systems [58] and drug conjugates, and have shown excellent biocompatibilities and stealth properties in comparison to PEG standards $[59,60]$. Consequently, POX-based brushes were introduced in some recent reports by our group [61-64] and Jordan et al. [65-67] to fabricate bio-inert and functional coatings. In these specific applications, POX coatings showed improved antifouling properties and stability against oxidative degradation compared to PEG analogues $[63,64]$. In addition, a recent study by Jordan et al. [66] demonstrated how POX-based "grafted-from" brushes featuring tunable chain end chemistries and POX composition could effectively function as platforms for the controlled adhesion of cells.

In addition to PEG-based and POX-based (macro)monomers, several methacrylate-, acrylate- and acrylamide-based species were also efficiently grafted by controlled radical SIP in order to produce platforms for cell adhesion and proliferation. In many cases, these species allowed extensive conjugation of protein cues compared to PEG-based monomers, thus amplifying the cell response at the brush surface. Among the proposed chemistries, poly(acrylic acid) (PAA) and poly(methacrylic acid) (PMAA) brushes [68-70], poly(glycidil methacrylate) (PGMA) [71], poly(hydroxyethyl methacrylate) (PHEMA) and poly(hydroxypropyl methacrylate) [72] brush films proved as efficient platforms for enhancing the bioconjugation of cell adhesive cues and subsequent attachment of cells. Specifically, PAA and PMAA were applied to determine the effects of brush micro- and nanoarchitectures on the response of adhering cells. Chiang et al. [68] studied PAA brush micropatterns on silicon oxide surfaces as platforms for the adhesion of RBL mast cells (as shown in Fig. 4). In this report, unfunctionalized PAA grafts were shown to first repel cell spreading, which was initially concentrated at the silicon oxide surface. Subsequently, PAA brush patterns were shown to progressively accumulate the FN molecules secreted by the RBL cells within the brush architecture, which induced further spreading of the cell membrane on the PAA brush with incubation time. This platform also demonstrated the extraordinarily versatile character of brush films, which, thanks to their multifunctionality, controlled swelling and quasi-3-D architecture, can efficiently function as study boards for cell attachment and organization on synthetic ECM supports.

In other reports, multifunctional surfaces fabricated by graftedfrom polymer brushes were exploited to mediate surface attachment of cells through reversible coupling of carbohydrate species. Glucose-containing molecules and biopolymers often play a key role in cell-ECM interactions, which are specifically related to the metabolism of cancer cells. Since boronic acid is a typical ligand for carbohydrate-bearing species, boronate-containing polymer brushes featuring $\mathrm{N}$-acryloyl-m-aminophenylboronic acid were thermally grafted from both flat and nanostructured silicon surfaces in order to complex glucose-based biomolecules and subsequently mediate the adhesion of various cells lineages. Specifically, the controlled attachment of murine hybridoma (M2139), human acute myeloid leukaemia (KG1) and breast cancer cells (MCF-7) was successfully accomplished [73].

Multiple binding capability expressed by dense brushes has proved to be an effective alternative means to stimulate cell adhesion (with phenylboronic acid (PBA) in the anion form, at high $\mathrm{pH}$ values) through carbohydrate-mediated adhesion, and allowed subsequent "fast" release of the adhered cells in the presence of brush-capping glucose preparations complemented within the cell culture medium. The rate of responsiveness of this particular reversible brush-cell interaction was increased by varying the $\mathrm{pH}$ 
(a)

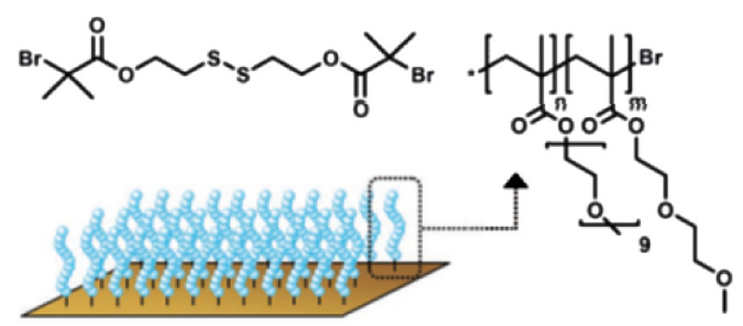

(b)
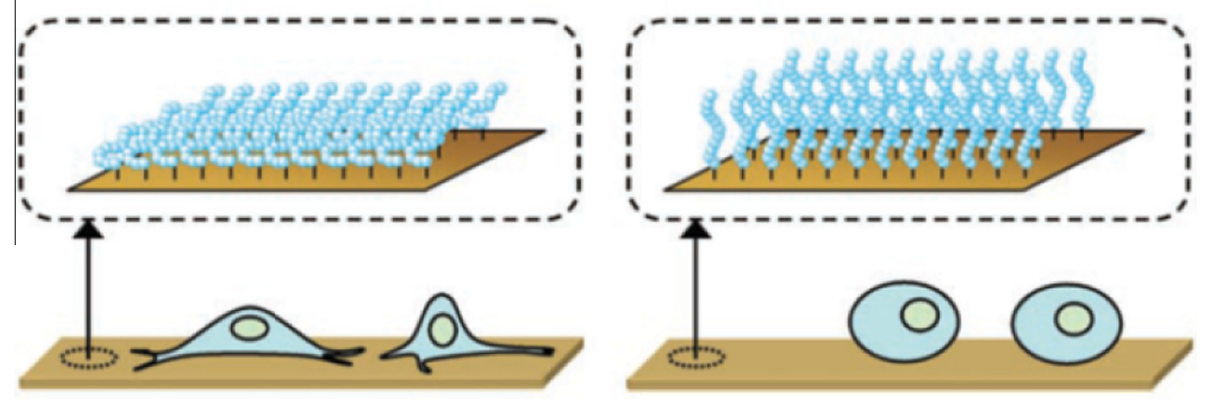

$37^{\circ} \mathrm{C}$ : adhesion
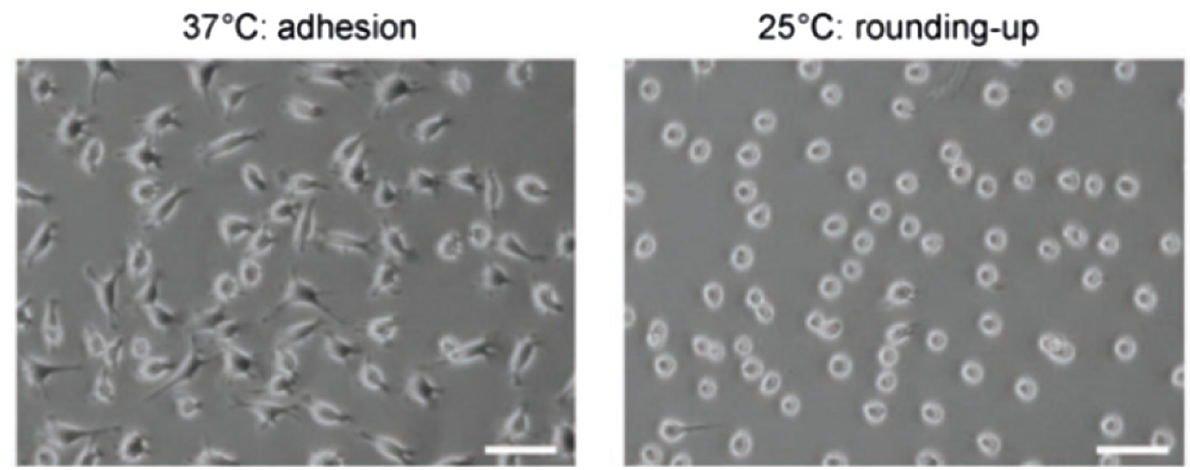

Fig. 2. The chemical composition of both ATRP initiator molecules assembled on Au surfaces and the subsequently grafted thermoresponsive OEGMA-based random copolymer (a). The surface-grafted POEGMA brushes were subsequently used for the reversible adhesion of L929 mouse fibroblasts across the brush LCST, as shown in the reported optical micrographs in (b). Adapted from Ref. [50].
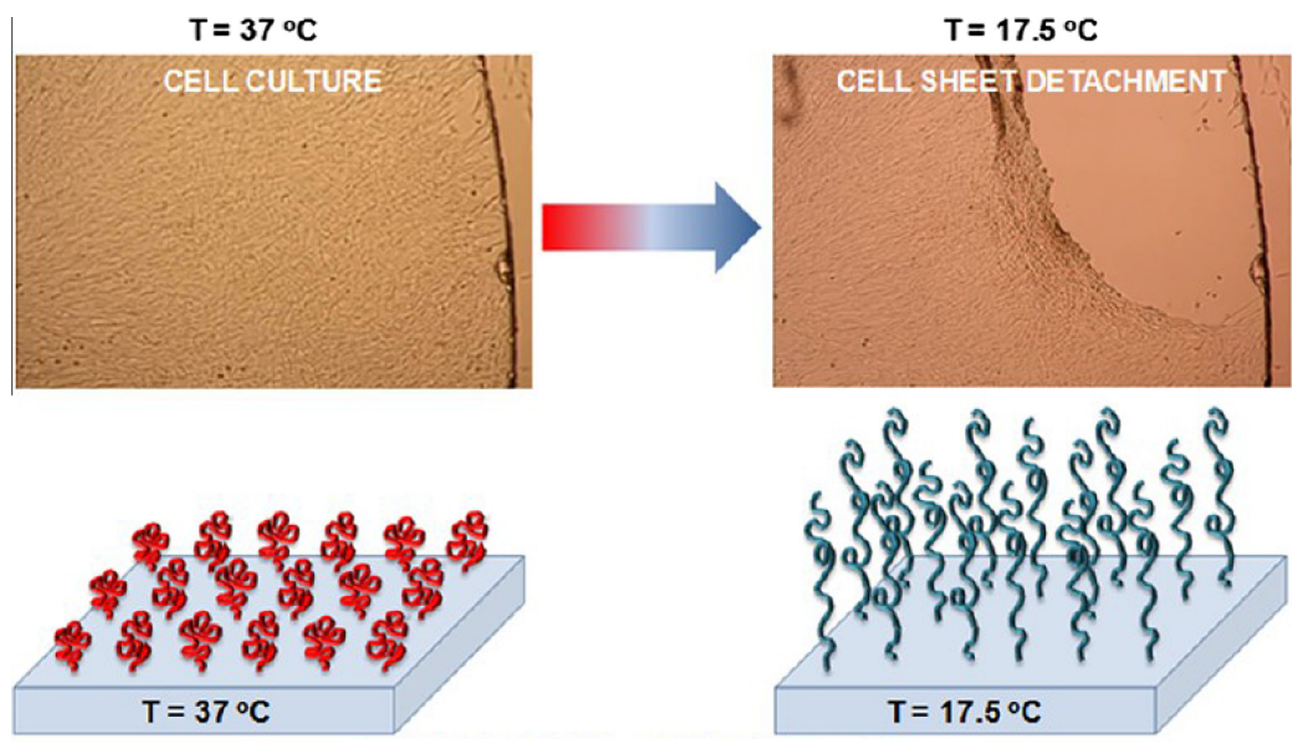

THERMOSENSITIVE P(TEGMA-EE) LAYERS

Fig. 3. Schematic depicting the thermoresponsive transition of poly[tri(ethylene glycol) monoethyl ether methacrylate] (P(TEGMA-EE)) brushes and the subsequent formation of a confluent fibroblast cell sheet. Adapted from Ref. [54]. 

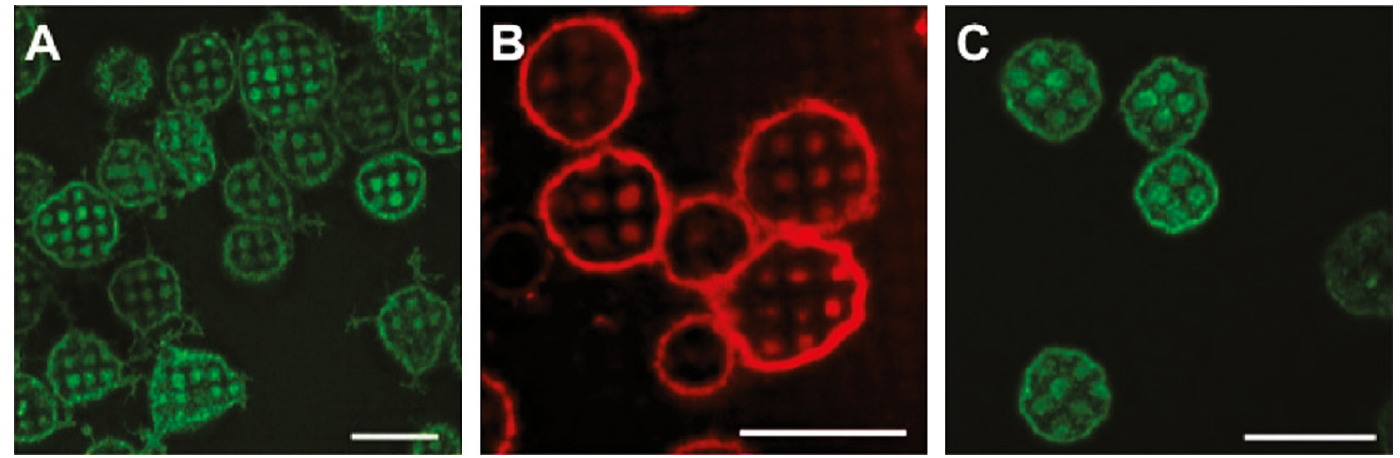

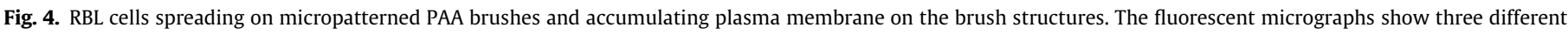

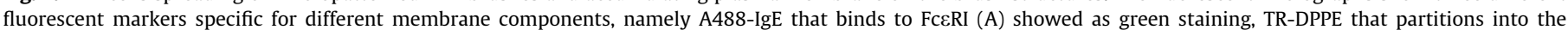
membrane lipid bilayer (B) (red staining) and A488-CTxB that binds to ganglioside GM1 (C) evidenced as green staining. Adapted with permission from [68].

of the medium, thus influencing the complexing ability of PBA moieties [74,75] (Fig. 5). Additionally, fully reversible and fast attachment-detachment cycles (which maintained high cell viability) were obtained by applying these brush coatings to high aspect-ratio surfaces like silicon-oxide nanowires, which has previously been proved to maximize the cell-surface interactions and response [73] (Fig. 5a,b).

The enhancement of biochemical interaction by multifunctional polymer brushes in comparison to monomolecular layers or SAMs was also exemplarily demonstrated by Sun and co-workers [76,77], who focused on the effects of chirality on cell behavior at surfaces. In these studies, the authors first showed how cells respond to different stereochemistry of SAMs, modulating their adhesion due to the intrinsic chiral character of the amino acids constituting the cell membrane proteins [76]. Secondly, they successfully demonstrated how the stereospecific adhesion of fibroblasts was substantially amplified by grafted-from brushes of poly $\mathrm{N}$-acryloyl-L(D)-amino acid. In particular, cells responded to L-films by enhanced spreading and attachment with lower apoptosis in comparison to the corresponding D-films [77]. The concept of (a)

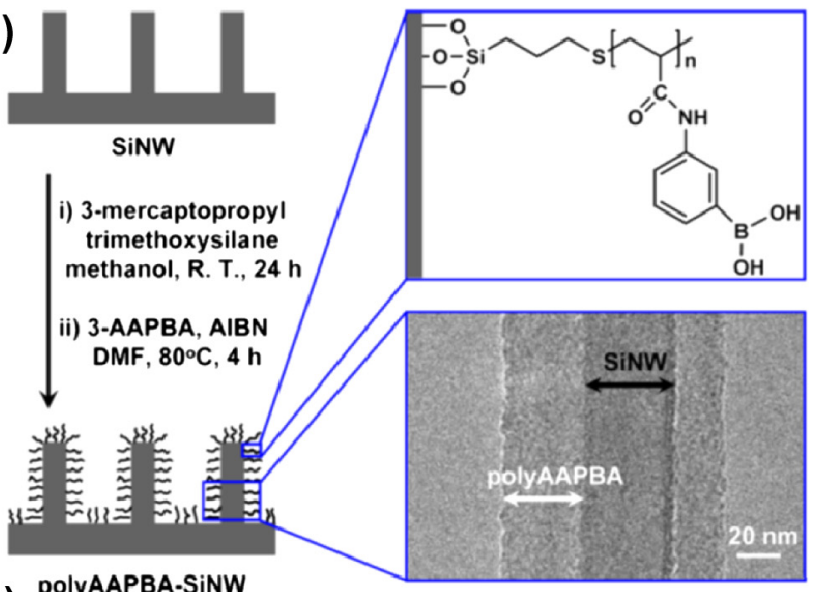

(b)

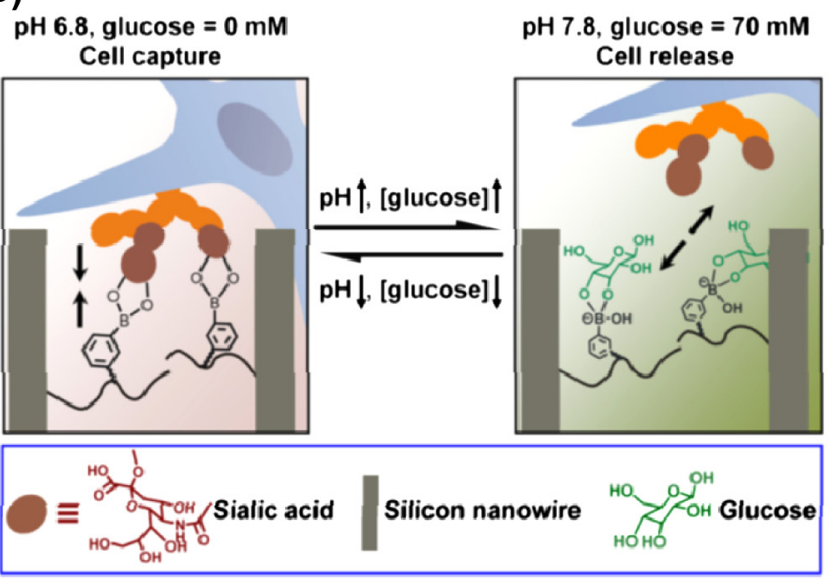

(c)

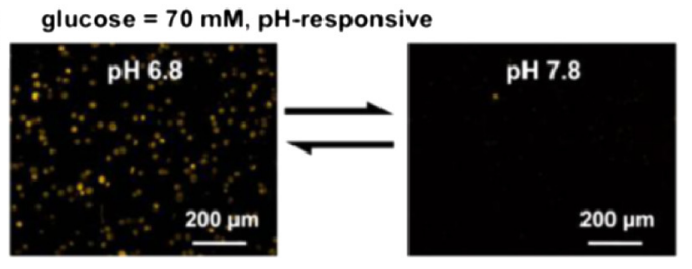

(d)

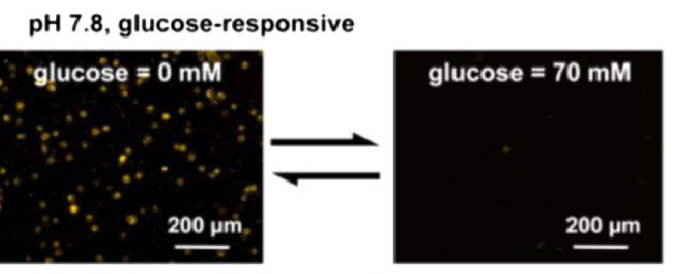

(e)

$\mathrm{pH}$ and glucose dual-responsive

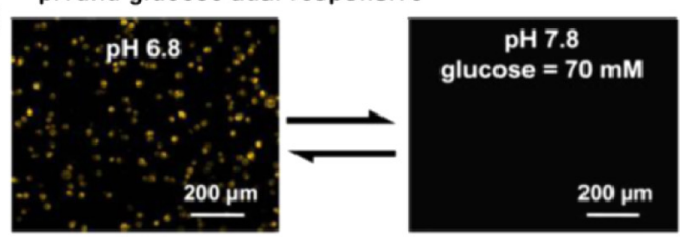

(f)

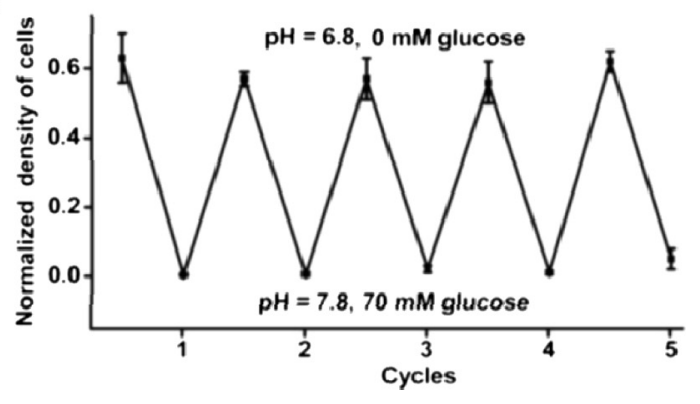

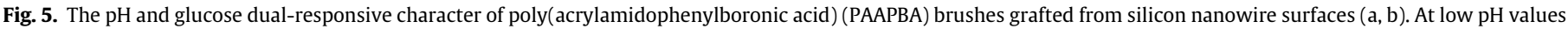

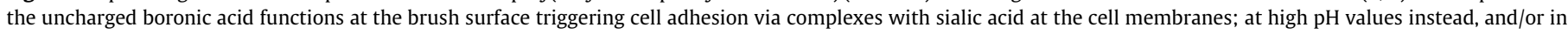

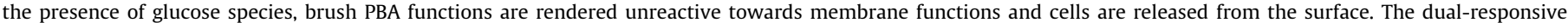

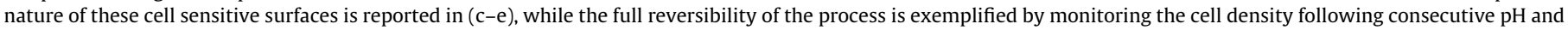
glucose concentration variations in (f). Figure adapted with permission from [73]. 

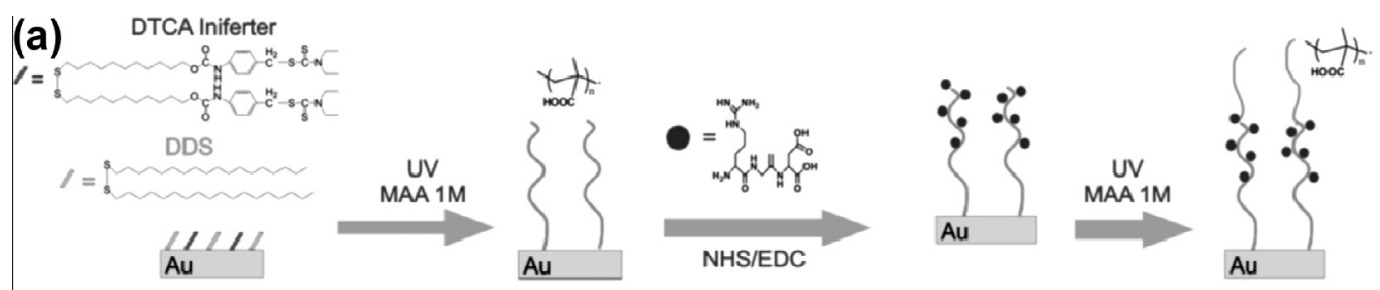

(b)
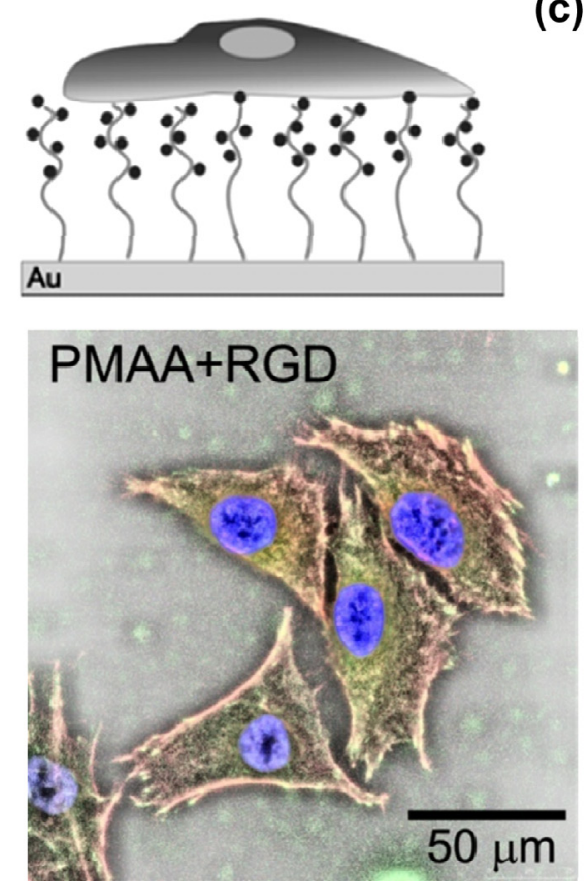

(c)
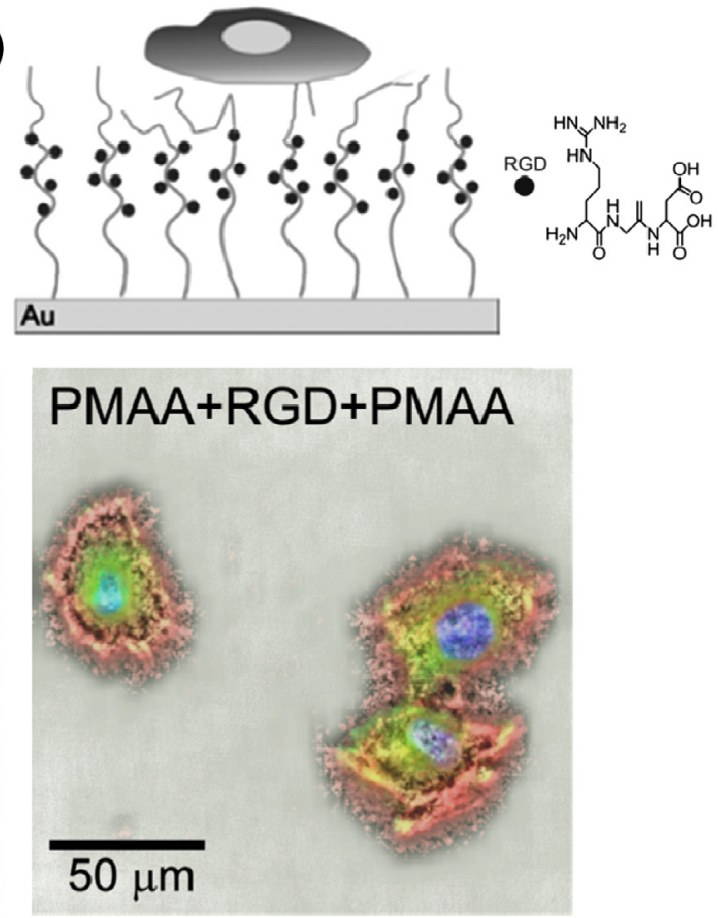

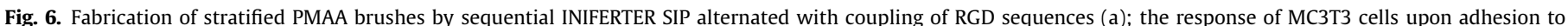

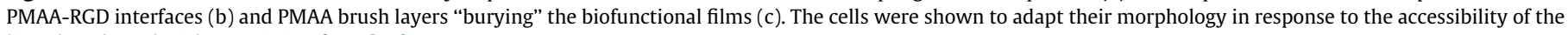
ligands. Adapted with permission from [69].

polymer brush multifunctionality was also applied and extended with the fabrication of layered brush structures and block-co-polyomer brushes as platforms for cell adhesion. These brush films were fabricated, for example, by Navarro et al. [69], who used the sequential photografting of methacrylic acid to obtain vertically structured PMAA brushes. PMAA brush films were first grafted by the INIFERTER SIP method, and subsequently functionalized with cell-adhesive RGD sequences. By the final reinitiation of SIP, the cell-adhesive brush layer could be "buried" under an additional PMAA layer. The thus vertically structured films were shown to induce different MC3T3 cell morphologies upon adhesion, where cells spread uniformly on RGD-rich interfaces while readapting their morphologies to more rounded ones when adhering on brush-covered RGD-brush conjugates (Fig. 6).

A step forward in the application of brush platforms beyond the promotion of cell adhesion and proliferation was accomplished by incorporating functions and/or biological cues which stimulate cell differentiation towards determined tissue types. This strategy brought the already well-developed bioconjugate brush films to more closely mimic ECM environments, thus stimulating the behavior of adhering cells first on flat surfaces [43] and later on surface-structured implants [78]. Following these approaches, GFs were covalently linked to poly(OEGMA-r-HEMA) brush surfaces along with cell adhesive cues in order to induce the differentiation of the pre-osteoblastic MC3T3-E1 cells [49]. Alternatively, random-co-polyomer brushes presenting both functionalizable HEMA monomers for adhesive peptides immobilization and phosphate-bearing methacrylates (MEP) to promote matrix mineralization were grafted and subsequently incubated in the presence of MC3T3-E1 (Fig. 7). By adjusting the co-monomers' relative concentrations, poly(HEMA-r-MEP) brushes kept biospecific characteristics and allowed efficient conjugation of GGGRGDS peptide sequences, thus enabling cell attachment on the brush surface. MEP functions concomitantly stimulated matrix mineralization by mimicking the natural composition of bone ECM [79].

The development of multifunctional brush platforms capable of directing the differentiation of cells quickly developed towards the application of pluripotent stem cells. This encompassed the application of chemically structured polymer brushes and stem cells on both flat study platforms and 3-D supports or implants for tissue regeneration. These topics are specifically addressed in Section 3 below.

\section{Thermoresponsive poly-N-(isopropyl acrylamide) (PNIPAM) brushes for cell manipulations}

The peculiar thermoresponsive properties of PNIPAM, i.e. a lower critical solution temperature (LCST) within physiological conditions at $30-32{ }^{\circ} \mathrm{C}$, have been exploited to fabricate polymer brush films alternatively presenting hydrophilic and hydrophobic characters by varying the temperature of the incubation medium $[21,80,81]$. An increase in temperature above LCST is accompanied by a coil-to-globule transition of PNIPAM-grafted chains, which allows the surface attachment of proteins from the culture medium 
(a)

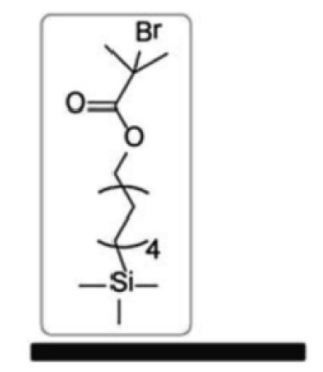
HEMA and HEMA and MEP
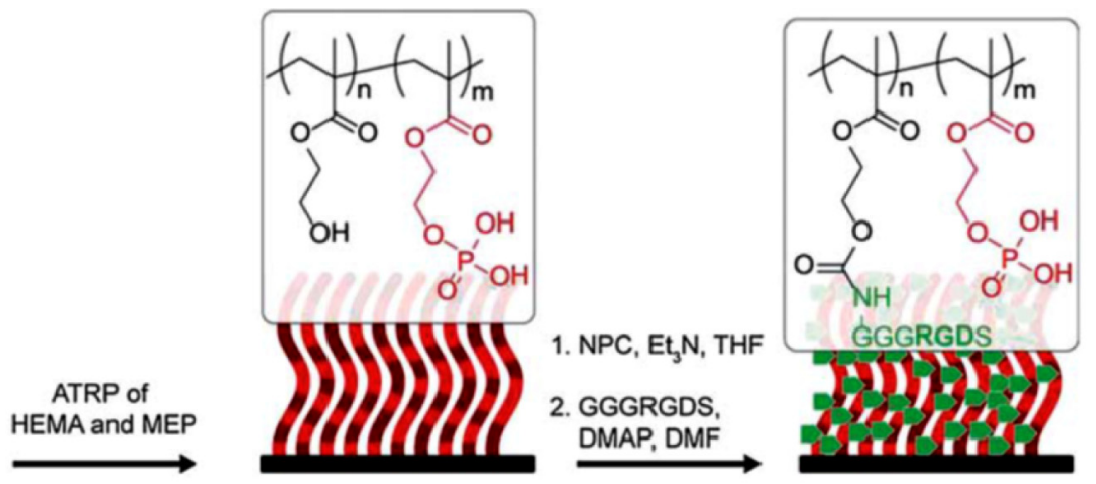

(b) $0 \%$ $4 \%$ $8 \%$ $23 \%$ $34 \%$

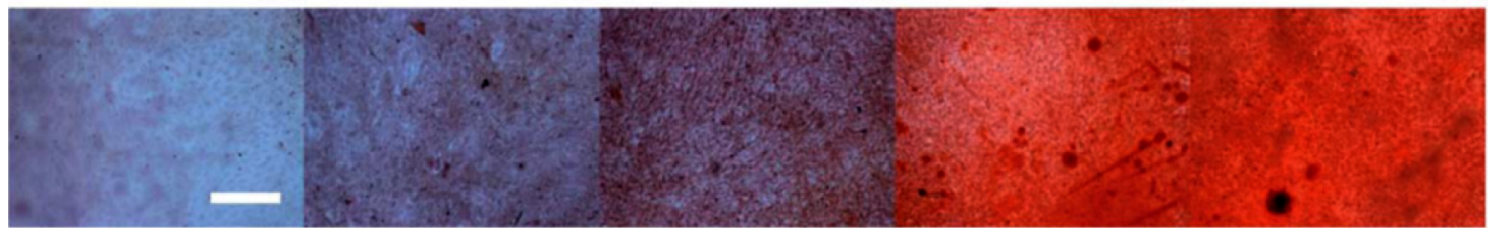



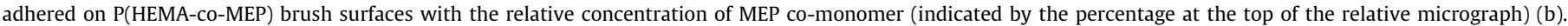
Adapted with permission from [79].

[82-88]. Thus, PNIPAM brushes undergo a transition from antibiofouling below their LCST to biofouling above it [89]. This transition was increasingly exploited during the last decade to control the adhesion of different cell types by producing reversibly adhesive substrates for culturing. In particularly, PNIPAM brushes were applied to develop “cell sheet engineering” by Yang et al. [90], providing an effective strategy for the fabrication of confluent assemblies of cells on thermally collapsed films which were subsequently released from the surface as self-standing sheets by simply lowering the culture temperature to below the LCST [91-99]. In these studies, the application of surface-grafted polymers presenting tunable cell-adhesive properties represented a substantial advance in comparison to the commonly used enzymatic treatments, which partially damage cells, ECMs and the cell-to-cell connections formed during culturing on solid substrates. As proven in several recent reports [91-100], cell attachment on PNIPAM brushes at $37^{\circ} \mathrm{C}$ (above the LCST) was caused by the collapse of grafted chains which favor primary and ternary adsorption of the cell adhesive protein cues present in the culture medium. This adsorption processes take place at the underlying substrate or SAM supporting the brush layer (also termed the "grafting surface"), and by chain-protein interaction within the brush (Fig. 8) [101,102]. Furthermore, these mechanisms were found to be favored over secondary adsorption, which involves protein attachment at the external brush-medium interface. Thus, adjustment of the brush grafting density and the chain length by the surface dilution of the initiator molecules and the application

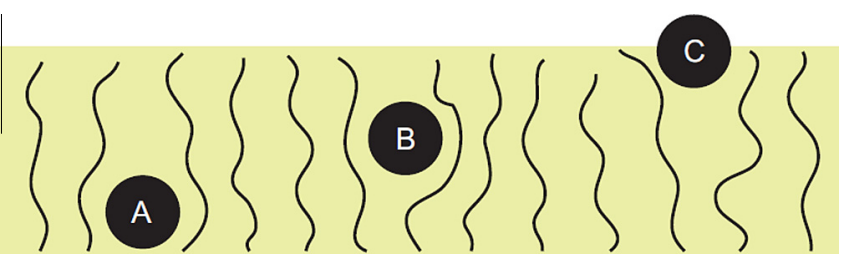

Fig. 8. Schematic depicting the different modes of protein adsorption on polymer brush surfaces: (A) primary adsorption at the grafting surface; (B) ternary adsorption due to polymer-protein interactions within the brush structure; (C) secondary adsorption at the brush-medium interface. Adapted with permission from [100]. of controlled radical SIPs (such as RAFT [91] or ATRP [97]) allowed the tuning of both cell attachment and detachment across the LCST.

Specifically, at high grafting densities protein adsorption is minimized both below and above the LCST due to hydration and, generally, to the osmotic pressure penalty that proteins have to overcome in adhering to an unperturbed brush surface [100]. In these cases, few cells could adhere to the collapsed PNIPAM brush except after long incubation times, particularly when the fabrication of confluent cell sheets was targeted. In contrast, cells detachment at temperatures below the LCST was favored by high grafting densities and longer chains due to the greater hydration and biorepellency of these brush systems when they are completely swollen [91].

These brush effects on cell adhesion and release across the LCST were all found to depend on the disjoining force between the protein-mediated surface attachment of cells and the osmotic pressure counterpart exerted by a reversibly collapsed or swollen brush interface [100]. The balance of these two forces, thus, determined the adhesion/release of cells from PNIPAM brushes.

Following these fabrication methods, Okano and coworkers successfully assembled cell sheets featuring diverse cell types, such as bovine carotid artery endothelial cells [91] and normal human dermal fibroblasts [92]. Epithelial cell sheets fabricated by PNIPAM brush-mediated attachment/proliferation/detachment were later successfully applied for corneal reconstruction [103,104] and transplanted to treat oesophageal ulcerations [105] (Fig. 9).

Reversible cell attachment on thermoresponsive brushes was also found to depend on the particular cell type. Specifically, if brush characteristics allowed indistinct adhesion of various cells, the rate of cell release from the PNIPAM surface at low temperatures depended on the characteristics of that particular cell line [97]. By exploiting this different behavior and carefully tuning brush length and grafting densities, different cells, co-cultured in the same medium were shown to adhere onto collapsed PNIPAM brushes above the LCST and be selectively released by lowering the temperature to below it. In this way, PNIPAM brush surfaces acted as effective cell separating platforms [95,97,98] (Fig. 10).

Several strategies were also applied to modify the chemical characteristics of PNIPAM brush layers in order to chemically tune 


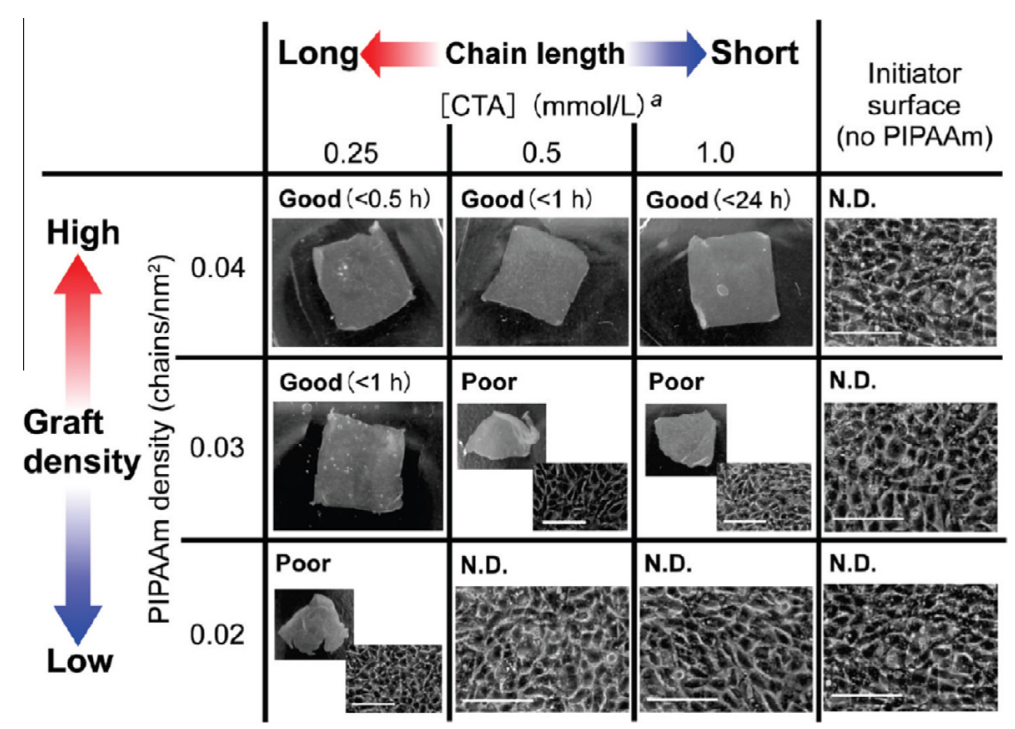

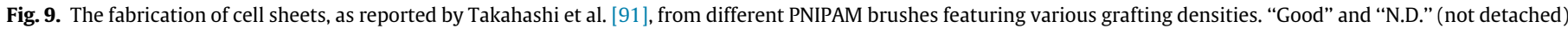

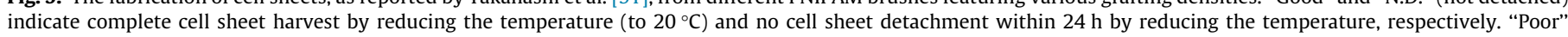

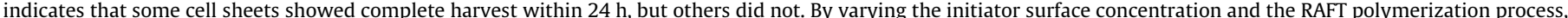

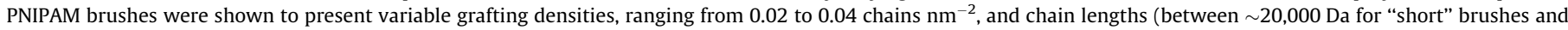
50,000 Da for "long" brushes). Adapted with permission from [91].

(A)

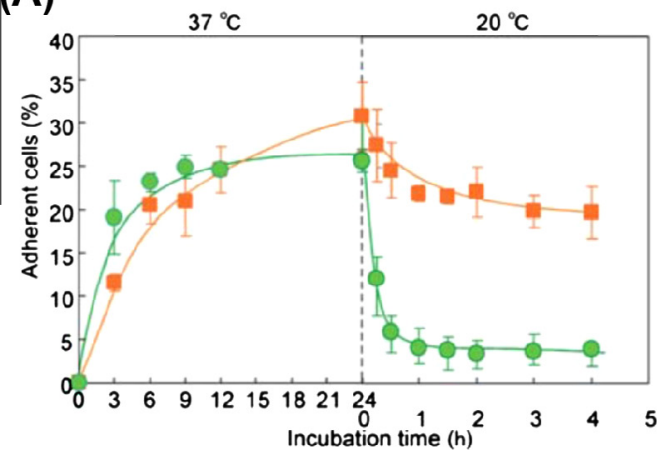

(B)

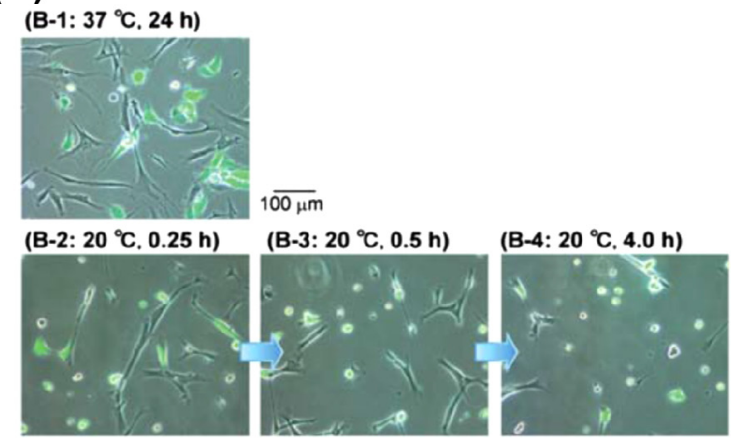

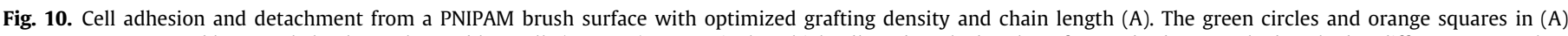

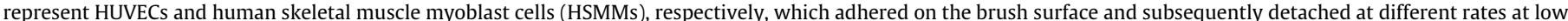

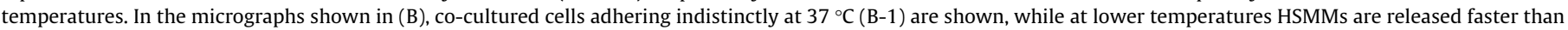
green fluorescent protein-expressing HUVECs (B-2 to B-4). Adapted with permission from [97].

the temperature-driven attachment/detachment of cells. Specifically, block-co-polymerization was applied to either introduce hydrophobic polystyrene segments at the outer brush interfaces [106] or co-monomers allowing coupling of cell adhesive cues [107]. Following similar synthetic strategies, RGD-functionalized PNIPAM-PAA co-polyomer brushes showed enhanced adhesion of human hepatocellular liver carcinoma cells (HepG2), while copolymerization of PNIPAM with 2-carboxyisopropylacrylamide (CIPAM) allowed the coupling of heparin functions on poly(NIPAM-co-CIPAM) brushes [99]. In this last case, the presence of heparin sites triggered the adhesion of cell-adhesive proteins and growth factors, thus inducing steady attachment and proliferation of mouse fibroblasts (NIH/3T3) above the polymer's LCST. Confluent cell sheets were subsequently released at lower culture temperatures.

Co-polymerizations of NIPAM with more hydrophilic (such as CIPAM, acrylic acid or 3-acrylamidopropyl triethylammonium chloride) and hydrophobic monomers (such as N-tertbutylacrylamide) were also applied from silica/glass microparticles in order to form thermoresponsive dispersible microparticles for cell culture. These systems were subsequently applied for large-scale culturing of mammalian cells (like Chinese hamster ovary cells) on dispersed microcarriers and showed the relevant enhancement of cell proliferation and subsequent viability in the absence of any sequential trypsinization $[94,96]$.

In summary, the application of PNIPAM-based brushes to produce a variety of reversible cell-adhesive platforms opened new possibilities not only for studying cell behavior at surfaces, but also to engineer cell sheets ready to transplantation, separate different cell types and improve the efficiency of cell cultivation methods. These approaches, featuring the application of a relatively "old" polymer on "new" fabrications, are increasingly revealing new efficiencies for the development of "intelligent" biomaterials.

\section{Polymer brushes directing stem cell behavior: next generation coatings for regenerative medicine}

As regenerative medicine strategies are focusing more and more on instructive biomaterials able to recruit cells in situ and steer their fate, polymer brushes can find a fertile ground in this field 

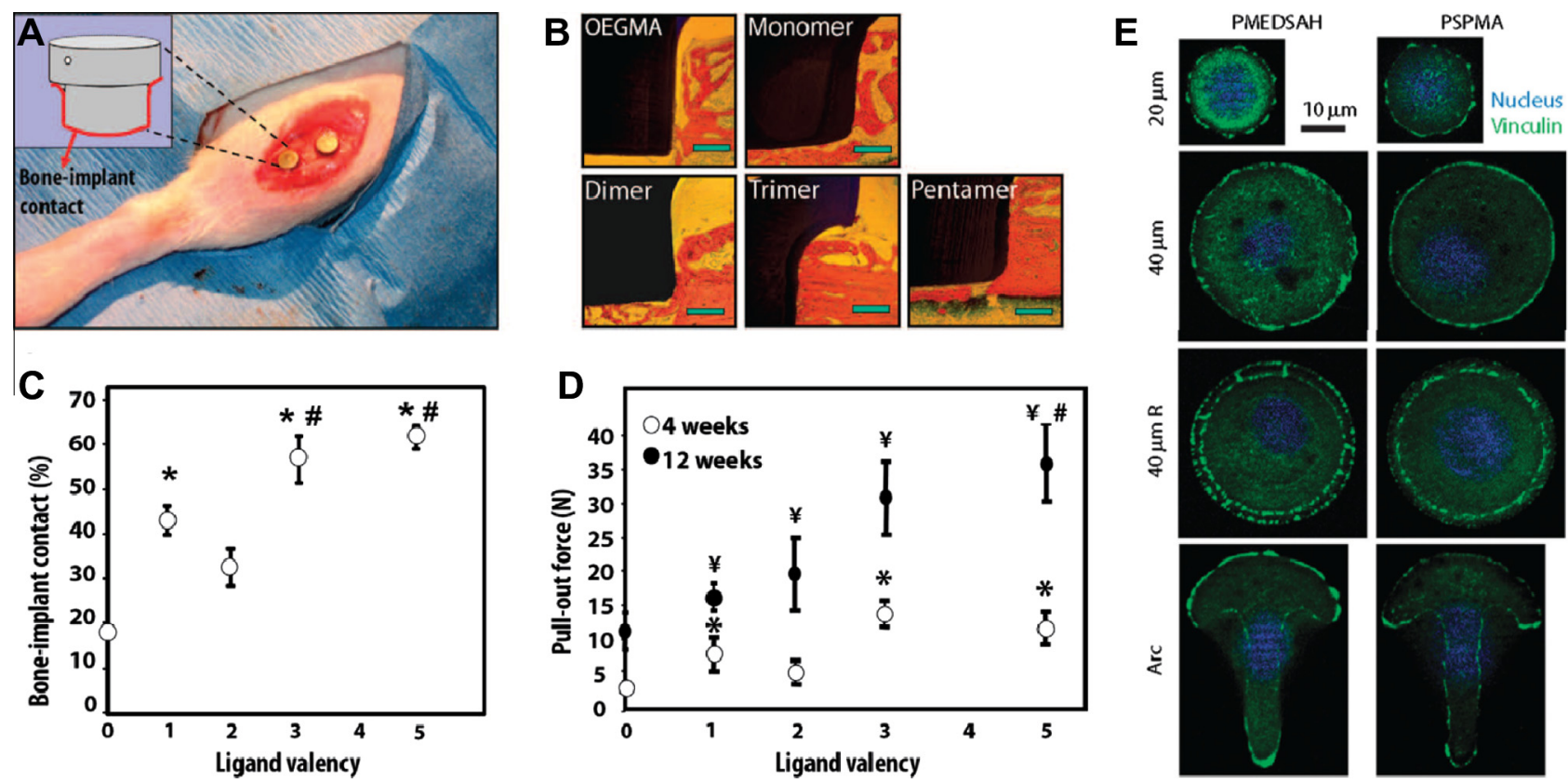

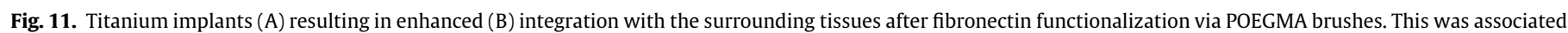

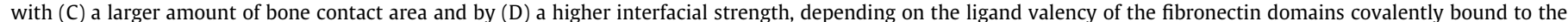

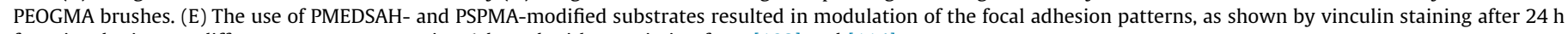
from incubation, on different pattern geometries. Adapted with permission from [108] and [114].

thanks to the flexibility with which they can be designed and synthesized on different substrates. We have previously discussed several examples where polymer brushes were used as smart linkers to present chemical moieties and biological cues to already specialized cells, thereby influencing their activity. This strategy could be even more powerful when applied to stem cells, which are known to be able to differentiate into several types of mature cells constituting tissues and organs in our body. In this respect, polymer brushes could serve as a powerful platform that has the potential to determine which tissues are formed, starting from a single cell source and depending on the precise degree of interaction with the chosen stem cell population. A few recent studies have shown, for example, that poly 2-(methacryloyloxy)ethyl]dimethyl-(3-sulfopropyl)ammoniumhydroxide (PMEDSAH) and POEGMA brushes can be used to selectively adhere bone marrow-derived mesenchymal stem cells (MSCs) [108]. While poly[ $N$-(3-sulfopropyl)- $N$ (methacryloxyethyl)- $N, N$-dimethylammoniumbetaine] (PSBMA) brushes were used only to show preliminarily selective adhesion of MSCs on the brush-functionalized culture substrates [109], POEGMA brushes were used to create functional linkers on medical grade titanium implants and covalent bind different FN domains that induced MSCs osteogenic differentiation through enhanced integrin-mediated adhesion [108]. When implanted in the tibias of rats, these functionalized implants result in a much better osteointegration than unfunctionalized titanium, thus proving that the brushes are also effective as smart linkers imparting instructive properties to biomaterials in vivo (Fig. 11).

Polymer brushes could also be used to provide physico-chemical and biological cues to study fundamental biological processes. To obtain a large number of cells for tissue engineering and regenerative medicine applications, cells need to be expanded. To do this, it is of pivotal importance to use highly defined culture conditions when using stem cells, so that the original undifferentiated cell phenotype can be maintained during the expansion. Polymer brushes can serve this purpose due to the close control that can be achieved when synthesizing them on a culture substrate. Poly (OEGMA-co-HEMA) and poly(L-lysine) brushes were used to culture human induced pluripotent stem cells and mouse fetal liver stem cells, respectively $[110,111]$. While the former brushes could maintain the stem cell phenotype unaltered for at least 10 passages [110], the latter films could regulate stem cell maintenance or differentiation into hepatocytes, depending on the brush density and, consequently, the substrate stiffness [111]. PMEDSAH brushes were also applied to maintain human embryonic stem cells in defined culture. Results showed that this was possible for up to 15-20 passages, and typical markers for the stem cell undifferentiated state were expressed at similar levels to when golden standard culture substrates like Matrigel were used [112]. Similarly, PSBMA grafting density was demonstrated to affect the degree of hydration of the underlying culture substrate and was shown to maintain hematopoietic stem and progenitor cells undifferentiated at an optimal density of $0.1 \mathrm{mg} \mathrm{cm}^{-2}$ [113].

Tan et al. [114] proposed an elegant approach to pattern defined geometrical micro-domains with different polymer brush chemistries, and study the influence of selectively adsorbed ECM domains on epidermal stem cell adhesion, morphology and differentiation. The authors showed that substrates with a negative potential were correlated with a higher degree of cell differentiation, which was connected to the formation of less focal adhesion despite there being no variations in cell morphology (Fig. 11). A similar approach was used to create microengineered epidermis, which can serve as an in vitro model to study drug toxicity and the phenomena that occur in the presence of disease cells, such as cancer cells [115].

Although studies showing the beneficial effect of polymer brushes to engineer the biological interface with stem cells are just starting to be published, the potential of polymer brushes is boundless. By tailoring their chemistry, spatial arrangement and length, we could envision creating new platform of biomaterials where more than a cell function can be accurately controlled and the biological function of more complex heterogeneous systems could be recapitulated synthetically. This would offer the tremendous possibility of decoupling each variable at the base of cell-cell and cell-substrate interactions, thus allowing us to understand regenerative and degenerative phenomena in greater depth, and could pose the basis for better therapies. 


\section{Conclusions and general perspectives}

Surface modification strategies featuring the application of polymer brushes have proved their versatility and applicability on a wide variety of biomaterials for the manipulation of cells. In this review, we have summarized the most relevant examples of these applications. All of the strategies have been shown to exploit a peculiar feature common to all grafted-from polymer brush surfaces: high densities of multifunctional tethered macromolecules can be tuned to mimic the characteristics and functions of natural ECM.

If most of the approaches presented have served to fabricate study boards for cell behavior in specific 2-D environments, direct applications for 3-D supports and ready-to-use implants are increasingly envisioned. A fundamental application in this respect would surely be represented by the engineering of scaffolds for the regeneration of tissues. This will require the synthesis of brush coatings on 3-D scaffolds to host and direct tissue (re)formation. This final goal will require new chemistries, featuring biodegradable and biocompatible brushes. In addition, bioconjugation with enzymatically degradable units and controlled functionalization will allow spatial and temporal definition over the interfacial activity of the brush films [116-121]. Moving towards more and more complex formulations that have the potential to recapitulate the heterogeneity of biological systems, polymer brushes could also be envisioned when biological gradients need to be implemented. This would open new horizons for the regeneration of functional tissues and organs where interfacial graded properties are required. Examples are the interfacial regions connecting tendons to muscles, ligaments to bones, and cartilage to subchondral bone for hard tissue regeneration, but also the graded variations within soft tissues, such as in the composition of skin, arteries and veins. Ultimately, the application of mixed polymer brushes selectively exposing different biological cues could be further envisioned. In this way, it would be possible to create biomaterials that provide differential cues not only for a targeted tissue regeneration, but also for its innervation and vascularization, thus progressing from tissue to organ regeneration with a unique and universal material technology platform.

\section{Appendix A. Figures with essential colour discrimination}

Certain figures in this article, particularly Figs. 1-11 are difficult to interpret in black and white. The full colour images can be found in the on-line version, at http://dx.doi.org/10.1016/j.actbio.2014. 02.048).

\section{References}

[1] Hidalgo-Bastida LA, Cartmell SH. Mesenchymal stem cells, osteoblasts and extracellular matrix proteins: enhancing cell adhesion and differentiation for bone tissue engineering. Tissue Eng B 2010;16:405-12.

[2] von der Mark K, Park J, Bauer S, Schmuki P. Nanoscale engineering of biomimetic surfaces: cues from the extracellular matrix. Cell Tissue Res 2010;339:131-53.

[3] Langer R, Vacanti JP. Tissue Engineering. Science 1993;260:920-6.

[4] Vacanti CA. History of tissue engineering and a glimpse into its future. Tissue Eng 2006;12:1137-42.

[5] Amass W, Amass A, Tighe B. A review of biodegradable polymers: uses, current developments in the synthesis and characterization of biodegradable polyesters, blends of biodegradable polymers and recent advances in biodegradation studies. Polym Int 1998;47:89-144.

[6] Fioretta ES, Fledderus JO, Burakowska-Meise EA, Baaijens FPT, Verhaar MC, Bouten CVC. Polymer-based scaffold designs for in situ vascular tissue engineering: controlling recruitment and differentiation behavior of endothelial colony forming cells. Macromol Biosci 2012;12:577-90.

[7] Ravichandran R, Sundarrajan S, Venugopal JR, Mukherjee S, Ramakrishna S. Advances in polymeric systems for tissue engineering and biomedical applications. Macromol Biosci 2012;12:286-311.

[8] Shin H, Jo S, Mikos AG. Biomimetic materials for tissue engineering. Biomaterials 2003;24:4353-64.
[9] Chen R, Hunt JA. Biomimetic materials processing for tissue-engineering processes. J Mater Chem 2007;17:3974-9.

[10] Senaratne W, Andruzzi L, Ober CK. Self-assembled monolayers and polymer brushes in biotechnology: current applications and future perspectives. Biomacromolecules 2005;6:2427-48.

[11] Raynor JE, Capadona JR, Collard DM, Petrie TA, Garcia AJ. Polymer brushes and self-assembled monolayers: versatile platforms to control cell adhesion to biomaterials. Biointerphases 2009;4:Fa3-Fa16.

[12] Edmondson S, Osborne VL, Huck WTS. Polymer brushes via surface-initiated polymerizations. Chem Soc Rev 2004;33:14-22.

[13] Zhao B, Brittain WJ. Polymer brushes: surface-immobilized macromolecules Prog Polym Sci 2000;25:677-710.

[14] Milner ST. Polymer brushes. Science 1991;251:905-14.

[15] Husseman M, Malmstrom EE, McNamara M, Mate M, Mecerreyes D, Benoit DG, et al. Controlled synthesis of polymer brushes by "living" free radical polymerization techniques. Macromolecules 1999;32:1424-31.

[16] Zdyrko B, Luzinov I. Polymer brushes by the "grafting to" method. Macromo Rapid Commun 2011;32:859-69.

[17] Pasetto P, Blas H, Audouin F, Boissiere C, Sanchez C, Save M, et al. Mechanistic insight into surface-initiated polymerization of methyl methacrylate and styrene via ATRP from ordered mesoporous silica particles. Macromolecules 2009;42:5983-95.

[18] Kruk M, Dufour B, Celer EB, Kowalewski T, Jaroniec M, Matyjaszewski K Grafting monodisperse polymer chains from concave surfaces of ordered mesoporous silicas. Macromolecules 2008;41:8584-91.

[19] Xiang P, Petrie K, Kontopoulou M, Ye ZB, Subramanian R. Tuning structura parameters of polyethylene brushes on silica nanoparticles in surfaceinitiated ethylene "living" polymerization and effects on silica dispersion in a polyolefin matrix. Polym Chem-UK 2013;4:1381-95.

[20] Koylu D, Carter KR. Stimuli-responsive surfaces utilizing cleavable polymer brush layers. Macromolecules 2009;42:8655-60.

[21] Benetti EM, Zapotoczny S, Vancso J. Tunable thermoresponsive polymeric platforms on gold by "photoiniferter"-based surface grafting. Adv Mater 2007; 19:268-71.

[22] Kang C, Crockett R, Spencer ND. Molecular-weight determination of polymer brushes generated by SI-ATRP on flat surfaces. Macromolecules 2014;47: 269-75.

[23] Matyjaszewski K, Xia JH. Atom transfer radical polymerization. Chem Rev 2001;101:2921-90.

[24] Siegwart DJ, Oh JK, Matyjaszewski K. ATRP in the design of functional materials for biomedical applications. Prog Polym Sci 2012;37:18-37.

[25] Otsu T. Iniferter concept and living radical polymerization. J Polym Sci A 2000;38:2121-36.

[26] Chiefari J, Chong YK, Ercole F, Krstina J, Jeffery J, Le TPT, et al. Living freeradical polymerization by reversible addition-fragmentation chain transfer: the RAFT process. Macromolecules 1998;31:5559-62.

[27] Mansky P, Liu Y, Huang E, Russell TP, Hawker C]. Controlling polymersurface interactions with random copolymer brushes. Science 1997;275: $1458-60$.

[28] Kim JB, Huang WX, Bruening ML, Baker GL. Synthesis of triblock copolymer brushes by surface-initiated atom transfer radical polymerization. Macromolecules 2002;35:5410-6.

[29] Boyes SG, Akgun B, Brittain WJ, Foster MD. Synthesis, characterization, and properties of polyelectrolyte block copolymer brushes prepared by atom transfer radical polymerization and their use in the synthesis of metal nanoparticles. Macromolecules 2003;36:9539-48.

[30] Brittain WJ, Boyes SG, Granville AM, Baum M, Mirous BK, Akgun B, et al. Surface rearrangement of diblock copolymer brushes - stimuli responsive films. Adv Polym Sci 2006;198:125-47.

[31] Wang X, Xiao X, Wang XH, Zhou JJ, Li L, Xu J. Reversibly switchable doubleresponsive block copolymer brushes. Macromol Rapid Commun 2007;28: $828-33$.

[32] Rowe MA, Hammer BAG, Boyes SG. Synthesis of surface-initiated stimuliresponsive diblock copolymer brushes utilizing a combination of ATRP and RAFT polymerization techniques. Macromolecules 2008;41:4147-57.

[33] Ignatova M, Voccia S, Gabriel S, Gilbert B, Cossement D, Jerome R, et al Stainless steel grafting of hyperbranched polymer brushes with an antibacterial activity: synthesis, characterization, and properties. Langmuir 2009;25:891-902.

[34] Banerjee I, Pangule RC, Kane RS. Antifouling coatings: recent developments in the design of surfaces that prevent fouling by proteins, bacteria, and marine organisms. Adv Mater 2011;23:690-718.

[35] Advincula RC, Brittain WJ, Caster KC, Ruhe J. Polymer Brushes: Synthesis Characterization. Applications. Weinheim: Wiley-VCH; 2004.

[36] Gillich T, Benetti EM, Rakhmatullina E, Konradi R, Li W, Zhang A, et al. Selfassembly of focal point oligo-catechol ethylene glycol dendrons on titanium oxide surfaces: adsorption kinetics, surface characterization, and nonfouling properties. J Am Chem Soc 2011;133:10940-50.

[37] Duan HW, Nie SM. Cell-penetrating quantum dots based on multivalent and endosome-disrupting surface coatings. J Am Chem Soc 2007;129: 3333-8.

[38] Gudipati CS, Finlay JA, Callow JA, Callow ME, Wooley KL. The antifouling and fouling-release perfomance of hyperbranched fluoropolymer (HBFP)poly(ethylene glycol) (PEG) composite coatings evaluated by adsorption of biomacromolecules and the green fouling alga Ulva. Langmuir 2005;21: 3044-53. 
[39] Ma HW, Hyun JH, Stiller P, Chilkoti A. "Non-fouling" oligo(ethylene glycol)functionalized polymer brushes synthesized by surface-initiated atom transfer radical polymerization. Adv Mater 2004;16:338-41.

[40] Brown AA, Khan NS, Steinbock L, Huck WTS. Synthesis of oligo(ethylene glycol) methacrylate polymer brushes. Eur Polym J 2005;41:1757-65.

[41] Tugulu S, Silacci P, Stergiopulos N, Klok HA. RGD-functionalized polymer brushes as substrates for the integrin specific adhesion of human umbilical vein endothelial cells. Biomaterials 2007;28:2536-46.

[42] Tugulu S, Klok HA. Stability and nonfouling properties of poly(poly (ethylene glycol) methacrylate) brushes under cell culture conditions. Biomacromolecules 2008;9:906-12.

[43] Raynor JE, Petrie TA, Garcia AJ, Collard DM. Controlling cell adhesion to titanium: functionalization of poly[oligo(ethylene glycol)methacrylate brushes with cell-adhesive peptides. Adv Mater 2007;19:1724-8.

[44] Singh N, Husson SM, Cui XF, Boland T. Polymer brush layers with variation of grafting density for peptide adsorption and cell adhesion studies. Abstr Pap Am Chem S 2006:231.

[45] Singh N, Cui XF, Boland T, Husson SM. The role of independently variable grafting density and layer thickness of polymer nanolayers on peptide adsorption and cell adhesion. Biomaterials 2007;28:763-71.

[46] Klein Gunnewiek M, Benetti EM, Di Luca A, van Blitterswijk CA, Moroni L, Vancso GJ. Thin polymer brush decouples biomaterial's micro-nanotopology and stem cell adhesion. Langmuir 2013:29:13843-52.

[47] Andruzzi L, Senaratne W, Hexemer A, Sheets ED, Ilic B, Kramer EJ, et al. Oligo(ethylene glycol) containing polymer brushes as bioselective surfaces. Langmuir 2005:21:2495-504.

[48] Tria MCR, Grande CDT, Ponnapati RR, Advincula RC. Electrochemical deposition and surface-initiated RAFT polymerization: protein and cell-resistant PPEGMEMA polymer brushes. Biomacromolecules 2010;11:3422-31.

[49] Ren XS, Wu YZ, Cheng Y, Ma HW, Wei SC. Fibronectin and bone morphogeneticprotein-2-decorated poly(OEGMA-r-HEMA) brushes promote osseointegration of titanium surfaces. Langmuir 2011;27:12069-73.

[50] Wischerhoff E, Uhlig K, Lankenau A, Borner HG, Laschewsky A, Duschl C, et al. Controlled cell adhesion on PEG-based switchable surfaces. Angew Chem Int Ed 2008;47:5666-8.

[51] Lutz JF, Hoth A. Preparation of ideal PEG analogues with a tunable thermosensitivity by controlled radical copolymerization of 2-(2-methoxyethoxy)ethyl methacrylate and oligo(ethylene glycol) methacrylate. Macromolecules 2006;39:893-6.

[52] Lutz JF, Weichenhan K, Akdemir O, Hoth A. About the phase transitions in aqueous solutions of thermoresponsive copolymers and hydrogels based on 2-(2-methoxyethoxy)ethyl methacrylate and oligo(ethylene glycol) methacrylate. Macromolecules 2007;40:2503-8.

[53] Uhlig K, Wischerhoff E, Lutz JF, Laschewsky A, Jaeger MS, Lankenau A, et al. Monitoring cell detachment on PEG-based thermoresponsive surfaces using TIRF microscopy. Soft Matter 2010;6:4262-7.

[54] Dworak A, Utrata-Wesolek A, Szweda D, Kowalczuk A, Trzebicka B, Aniol J et al. Poly[tri(ethylene glycol) ethyl ether methacrylate]-coated surfaces for controlled fibroblasts culturing. ACS Appl Mater Inter 2013;5:2197-207.

[55] Hoogenboom R. Poly(2-oxazoline)s: a polymer class with numerous potential applications. Angew Chem Int Ed 2009;48:7978-94.

[56] Tong J, Zimmerman MC, Li SM, Yi X, Luxenhofer R, Jordan R, et al. Neuronal uptake and intracellular superoxide scavenging of a fullerene (C-60)-poly(2oxazoline)s nanoformulation. Biomaterials 2011;32:3654-65.

[57] Tong J, Yi X, Luxenhofer R, Banks WA, Jordan R, Zimmerman MC, et al. Conjugates of superoxide dismutase 1 with amphiphilic poly(2-oxazoline) block copolymers for enhanced brain delivery: synthesis, characterization and evaluation in vitro and in vivo. Mol Pharm 2013;10:360-77.

[58] Luxenhofer R, Han YC, Schulz A, Tong J, He ZJ, Kabanov AV, et al. Poly(2oxazoline)s as polymer therapeutics. Macromol Rapid Commun 2012:33:1613-31.

[59] Viegas TX, Bentley MD, Harris JM, Fang ZF, Yoon K, Dizman B, et al. Polyoxazoline: chemistry, properties, and applications in drug delivery. Bioconjugate Chem 2011:22:976-86.

[60] Mero A, Fang ZH, Pasut G, Veronese FM, Viegas TX. Selective conjugation of poly(2-ethyl 2-oxazoline) to granulocyte colony stimulating factor. J Control Release 2012;159:353-61.

[61] Konradi R, Pidhatika B, Muhlebach A, Textort M. Poly 2-methyl-2-oxazoline: a peptide-like polymer for protein-repellent surfaces. Langmuir 2008;24: 613-6.

[62] Pidhatika B, Moller J, Benetti EM, Konradi R, Rakhmatullina E, Muhlebach A, et al. The role of the interplay between polymer architecture and bacterial surface properties on the microbial adhesion to polyoxazoline-based ultrathin films. Biomaterials 2010;31:9462-72.

[63] Konradi R, Acikgoz C, Textor M. Polyoxazolines for nonfouling surface coatings - a direct comparison to the gold standard PEG. Macromol Rapid Commun 2012;33:1663-76.

[64] Pidhatika B, Rodenstein M, Chen Y, Rakhmatullina E, Muhlebach A, Acikgoz C et al. Comparative stability studies of poly(2-methyl-2-oxazoline) and poly(ethylene glycol) brush coatings. Biointerphases 2012:7.

[65] Hutter NA, Reitinger A, Garrido JA, Jordan R. Biofunctionalization of patterned poly(2-oxazoline) bottle-brush-brushes on diamond. Abstr Pap Am Chem S 2012:243.

[66] Zhang N, Pompe T, Amin I, Luxenhofer R, Werner C, Jordan R. Tailored poly(2oxazoline) polymer brushes to control protein adsorption and cell adhesion. Macromol Biosci 2012;12:926-36.
[67] Zhang N, Pompe T, Luxenhofer R, Werner C, Jordan R. Poly(2-oxazoline) bottle-brush brushes for the control of protein adsoption and cell adhesion. Abstr Pap Am Chem S 2012:243.

[68] Chiang EN, Dong R, Ober CK, Baird BA. Cellular responses to patterned poly(acrylic acid) brushes. Langmuir 2011:27:7016-23.

[69] Navarro M, Benetti EM, Zapotoczny S, Planell JA, Vancso GJ. Buried, covalently attached RGD peptide motifs in poly(methacrylic acid) brush layers: the effect of brush structure on cell adhesion. Langmuir 2008;24:10996-1002.

[70] Yuan SJ, Xiong G, Wang XY, Zhang S, Choong C. Surface modification of polycaprolactone substrates using collagen-conjugated poly(methacrylic acid) brushes for the regulation of cell proliferation and endothelialisation. J Mater Chem 2012;22:13039-49.

[71] Yuan SJ, Xiong G, Roguin A, Choong C. Immobilization of gelatin onto poly(glycidyl methacrylate)-grafted polycaprolactone substrates for improved cell-material interactions. Biointerphases 2012:7.

[72] Ren TC, Mao ZW, Guo J, Gao CY. Directional migration of vascular smooth muscle cells guided by a molecule weight gradient of poly(2-hydroxyethyl methacrylate) brushes. Langmuir 2013;29:6386-95.

[73] Liu HL, Li YY, Sun K, Fan JB, Zhang PC, Meng JX, et al. Dual-responsive surfaces modified with phenylboronic acid-containing polymer brush to reversibly capture and release cancer cells. J Am Chem Soc 2013;135:7603-9.

[74] Ivanov AE, Eccles J, Panahi HA, Kumar A, Kuzimenkova MV, Nilsson L, et al. Boronate-containing polymer brushes: characterization, interaction with saccharides and mammalian cancer cells. J Biomed Mater Res A 2009;88A:213-25.

[75] Ivanov AE, Kumar A, Nilsang S, Aguilar MR, Mikhalovska LI, Savina IN, et al. Evaluation of boronate-containing polymer brushes and gels as substrates for carbohydrate-mediated adhesion and cultivation of animal cells. Colloid Surf B 2010;75:510-9.

[76] Sun TL, Han D, Rhemann K, Chi LF, Fuchs H. Stereospecific interaction between immune cells and chiral surfaces. J Am Chem Soc 2007;129:1496.

[77] Wang X, Gan H, Sun TL, Su BL, Fuchs H, Vestweber D, et al. Stereochemistry triggered differential cell behaviours on chiral polymer surfaces. Soft Matter 2010;6:3851-5

[78] Petrie TA, Raynor JE, Reyes CD, Burns KL, Collard DM, Garcia AJ. The effect of integrin-specific bioactive coatings on tissue healing and implant osseointegration. Biomaterials 2008;29:2849-57.

[79] Paripovic D, Hall-Bozic H, Klok HA. Osteoconductive surfaces generated from peptide functionalized poly(2-hydroxyethyl methacrylate-co-2(methacryloyloxy)ethyl phosphate) brushes. J Mater Chem 2012;22: 19570-8.

[80] Yim H, Kent MS, Mendez S, Balamurugan SS, Balamurugan S, Lopez GP, et al. Temperature-dependent conformational change of PNIPAM grafted chains at high surface density in water. Macromolecules 2004;37:1994-7.

[81] Plunkett KN, Zhu X, Moore JS, Leckband DE. PNIPAM chain collapse depends on the molecular weight and grafting density. Langmuir 2006;22:4259-66.

[82] Jones DM, Smith JR, Huck WTS, Alexander C Variable adhesion of micropatterned thermoresponsive polymer brushes: AFM investigations of poly (N-isopropylacrylamide) brushes prepared by surface-initiated polymerizations. Adv Mater 2002;14:1130-4.

[83] Kaholek M, Lee WK, Ahn SJ, Ma HW, Caster KC, LaMattina B, et al. Stimulusresponsive poly( $\mathrm{N}$-isopropylacrylamide) brushes and nanopatterns prepared by surface-initiated polymerization. Chem Mater 2004;16:3688-96.

[84] Canavan HE, Cheng XH, Graham DJ, Ratner BD, Castner DG. Surface characterization of the extracellular matrix remaining after cell detachment from a thermoresponsive polymer. Langmuir 2005;21:1949-55.

[85] Ista LK, Mendez S, Perez-Luna VH, Lopez GP. Synthesis of poly $(\mathrm{N}$ isopropylacrylamide) on initiator-modified self-assembled monolayers. Langmuir 2001;17:2552-5.

[86] Cho EC, Kim YD, Cho K. Thermally responsive poly (N-isopropylacrylamide) monolayer on gold: synthesis, surface characterization, and protein interaction/adsorption studies. Polymer 2004;45:3195-204.

[87] Magoshi T, Ziani-Cherif H, Ohya S, Nakayama Y, Matsuda T. Thermoresponsive heparin coating: heparin conjugated with $\operatorname{poly}(\mathrm{N}$ isopropylacrylamide) at one terminus. Langmuir 2002;18:4862-72.

[88] Xue CY, Yonet-Tanyeri N, Brouette N, Sferrazza M, Braun PV, Leckband DE. Protein adsorption on poly(N-isopropylacrylamide) brushes: dependence on grafting density and chain collapse. Langmuir 2011;27:8810-8.

[89] Alarcon CDH, Farhan T, Osborne VL, Huck WTS, Alexander C. Bioadhesion at micro-patterned stimuli-responsive polymer brushes. J Mater Chem 2005; 15:2089-94.

[90] Yang J, Yamato M, Kohno C, Nishimoto A, Sekine H, Fukai F, et al. Cell sheet engineering: recreating tissues without biodegradable scaffolds. Biomaterials 2005;26:6415-22.

[91] Takahashi H, Nakayama M, Yamato M, Okano T. Controlled chain length and graft density of thermoresponsive polymer brushes for optimizing cell sheet harvest. Biomacromolecules 2010;11:1991-9.

[92] Takahashi H, Nakayama M, Itoga K, Yamato M, Okano T. Micropatterned thermoresponsive polymer brush surfaces for fabricating cell sheets with well-controlled orientational structures. Biomacromolecules 2011;12: 1414-8.

[93] Nagase K, Watanabe M, Kikuchi A, Yamato M, Okano T. Thermo-responsive polymer brushes as intelligent biointerfaces: preparation via ATRP and characterization. Macromol Biosci 2011;11:400-9.

[94] Tamura A, Nishi M, Kobayashi J, Nagase K, Yajima H, Yamato M, et al. Simultaneous enhancement of cell proliferation and thermally induced 
harvest efficiency based on temperature-responsive cationic copolymergrafted microcarriers. Biomacromolecules 2012;13:1765-73.

[95] Nagase K, Mukae N, Kikuchi A, Okano T. Thermally modulated retention of lymphoctytes on polymer-brush-grafted glass beads. Macromol Biosci 2012;12:333-40.

[96] Tamura A, Kobayashi J, Yamato M, Okano T. Thermally responsive microcarriers with optimal poly(N-isopropylacrylamide) grafted density for facilitating cell adhesion/detachment in suspension culture. Acta Biomater 2012;8:3904-13.

[97] Nagase K, Kimura A, Shimizu T, Matsuura K, Yamato M, Takeda N, et al. Dynamically cell separating thermo-functional biointerfaces with densely packed polymer brushes. J Mater Chem 2012;22:19514-22.

[98] Nagase K, Hatakeyama Y, Shimizu T, Matsuura K, Yamato M, Takeda N, et al. Hydrophobized thermoresponsive copolymer brushes for cell separation by multistep temperature change. Biomacromolecules 2013;14:3423-33.

[99] Arisaka Y, Kobayashi J, Yamato M, Akiyama Y, Okano T. Switching of cell growth/detachment on heparin-functionalized thermoresponsive surface for rapid cell sheet fabrication and manipulation. Biomaterials 2013;34: 4214-22.

[100] Halperin A, Kroger M. Theoretical considerations on mechanisms of harvesting cells cultured on thermoresponsive polymer brushes. Biomaterials 2012;33:4975-87.

[101] Choi S, Choi BC, Xue CY, Leckband D. Protein adsorption mechanisms determine the efficiency of thermally controlled cell adhesion on poly $(\mathrm{N}-$ isopropyl acrylamide) brushes. Biomacromolecules 2013;14:92-100.

[102] Xue CY, Choi BC, Choi S, Braun PV, Leckband DE. Protein adsorption modes determine reversible cell attachment on poly( $\mathrm{N}$-isopropyl acrylamide) brushes. Adv Funct Mater 2012;22:2394-401.

[103] Nishida K, Yamato M, Hayashida Y, Watanabe K, Yamamoto K, Adachi E, et al. Corneal reconstruction with tissue-engineered cell sheets composed of autologous oral mucosal epithelium. New Engl J Med 2004;351:1187-96.

[104] Kobayashi T, Kan K, Nishida K, Yamato M, Okano T. Corneal regeneration by transplantation of corneal epithelial cell sheets fabricated with automated cell culture system in rabbit model. Biomaterials 2013;34:9010-7.

[105] Ohki T, Yamato M, Murakami D, Takagi R, Yang J, Namiki H, et al. Treatment of oesophageal ulcerations using endoscopic transplantation of tissueengineered autologous oral mucosal epithelial cell sheets in a canine model. Gut 2006;55:1704-10.

[106] Yu Q, Zhang YX, Chen H, Zhou F, Wu ZQ, Huang H, et al. Protein adsorption and cell adhesion/detachment behavior on dual-responsive silicon surfaces modified with poly(N-isopropylacrylamide)-block-polystyrene copolymer. Langmuir 2010;26:8582-8.

[107] Li LH, Wu JD, Gao CY. Gradient immobilization of a cell adhesion RGD peptide on thermal responsive surface for regulating cell adhesion and detachment. Colloid Surface B 2011;85:12-8.
[108] Petrie TA, Raynor JE, Dumbauld DW, Lee TT, Jagtap S, Templeman KL, et al Multivalent integrin-specific ligands enhance tissue healing and biomaterial integration. Sci Transl Med 2010;2:45ra60.

[109] Steinbach A, Tautzenberger A, Ignatius A, Pluntke M, Marti O, Volkmer D. Coatings from micropatterned sulfobetaine polymer brushes as substrates for MC3T3-E1 cells. J Mater Sci 2012;23:573-9.

[110] Deng Y, Zhang X, Zhao X, Li Q, Ye Z, Li Z, et al. Long-term self-renewal of human pluripotent stem cells on peptide-decorated poly(OEGMA-co-HEMA) brushes under fully defined conditions. Acta Biomater 2013;9:8840-50.

[111] Tsai HA, Shen CN, Chang YC. Use of surface properties to control the growth and differentiation of mouse fetal liver stem/progenitor cell colonies. Biomacromolecules 2012;13:3483-93.

[112] Villa-Diaz LG, Nandivada H, Ding J, Nogueira-de-Souza NC, Krebsbach PH O'Shea KS, et al. Synthetic polymer coatings for long-term growth of human embryonic stem cells. Nat Biotechnol 2010;28:581-3.

[113] Chang Y, Higuchi A, Shih YJ, Li PT, Chen WY, Tsai EM, et al. Bioadhesive control of plasma proteins and blood cells from umbilical cord blood onto the interface grafted with zwitterionic polymer brushes. Langmuir 2012:28:4309-17.

[114] Tan KY, Lin H, Ramstedt M, Watt FM, Huck WT, Gautrot JE. Decoupling geometrical and chemical cues directing epidermal stem cell fate on polymer brush-based cell micro-patterns. Integrative biology: quantitative biosciences from nano to macro 2013;5:899-910.

[115] Gautrot JE, Wang C, Liu X, Goldie SJ, Trappmann B, Huck WT, et al. Mimicking normal tissue architecture and perturbation in cancer with engineered micro-epidermis. Biomaterials 2012;33:5221-9.

[116] Kloxin AM, Kasko AM, Salinas CN, Anseth KS. Photodegradable hydrogels for dynamic tuning of physical and chemical properties. Science 2009;324: 59-63.

[117] Hahn MS, Miller JS, West JL. Three-dimensional biochemical and biomechanical patterning of hydrogels for guiding cell behavior. Adv Mater 2006; 18:2679-84.

[118] Lutolf MR, Weber FE, Schmoekel HG, Schense JC, Kohler T, Muller R, et al Repair of bone defects using synthetic mimetics of collagenous extracellular matrices. Nat Biotechnol 2003;21:513-8.

[119] Lutolf MP, Hubbell JA. Synthetic biomaterials as instructive extracellular microenvironments for morphogenesis in tissue engineering. Nat Biotechnol 2005;23:47-55.

[120] Lutolf MP, Lauer-Fields JL, Schmoekel HG, Metters AT, Weber FE, Fields GB, et al. Synthetic matrix metalloproteinase-sensitive hydrogels for the conduction of tissue regeneration: engineering cell-invasion characteristics. Proc Natl Acad Sci U S A 2003;100:5413-8.

[121] Wylie RG, Ahsan S, Aizawa Y, Maxwell KL, Morshead CM, Shoichet MS Spatially controlled simultaneous patterning of multiple growth factors in three-dimensional hydrogels. Nat Mater 2011;10:799-806. 